\title{
When populists become popular: Comparing Facebook use by the right-wing movement Pegida and German political parties
}

\author{
Sebastian Stier ${ }^{\mathrm{a}}$, Lisa Posch ${ }^{\mathrm{a}, \mathrm{b}}$, Arnim Bleier $^{\mathrm{a}}$ and Markus Strohmaier ${ }^{\mathrm{a}, \mathrm{b}}$ \\ ${ }^{a}$ Department Computational Social Science, GESIS - Leibniz Institute for the Social \\ Sciences, Cologne, Germany; ${ }^{b}$ Department of Computer Science, University of \\ Koblenz-Landau, Koblenz, Germany
}

\begin{abstract}
Previous research has acknowledged the use of social media in political communication by right-wing populist parties and politicians. Less is known, however, about its pivotal role for right-wing social movements which rely on personalized messages to mobilize supporters and challenge the mainstream party system. This paper analyzes online political communication by the right-wing populist movement Pegida and German political parties. We investigate to which extent parties attract supporters of Pegida, to which extent they address topics similar to Pegida and whether their topic use has become more similar over a period of almost two years. The empirical analysis is based on Facebook posts by main accounts and individual representatives of these political groups. We first show that there are considerable overlaps in the audiences of Pegida and the new challenger in the party system, AfD. Then we use topic models to characterize topic use by party and surveyed crowdworkers to which extent they perceive the identified topics as populist communication. The results show that while Pegida and AfD talk about rather unique topics and niche parties engage to varying degrees with the topics populists emphasize, the two governing parties CDU and SPD clearly deemphasize those. Overall, the findings indicate that the considerable attention devoted to populist actors and shifts in public opinion due to the refugee crisis have left only moderate marks in political communication within the mainstream party system.
\end{abstract}

Keywords: Political communication; populism; protest movements; party politics; topic modeling; Facebook

Published in Information, Communication $\&$ Society DOI: https://doi.org/10.1080/1369118X.2017.1328519 


\section{Introduction}

Right-wing populist forces are challenging the established political order across the western world. Previous research on populism has acknowledged the pivotal role of social media in these processes, enabling populist parties and politicians to bypass media gatekeepers and transmit direct messages to target audiences (Arzheimer, 2015; Engesser, Ernst, Esser, \& Büchel, 2016). At the same time, the technological opportunity structures of right-wing social movements like the Tea Party or the alt-right in the U.S. have also improved significantly since the advent of social media. These phenomena are less well understood, since previous social movement research mostly focused on how leftist and anti-authoritarian groups communicate, mobilize and organize collective action (e.g. Bennett, Segerberg, \& Walker, 2014; González-Bailón \& Wang, 2016). Furthermore, the sociotechnical characteristics of social media make it a unique venue for direct interactions between social movements, their supporters and parties, a core mechanism how emerging societal ideas are established in democracies (McAdam \& Tarrow, 2010). To address these gaps at the intersection of several research fields, we concentrate on contemporary German politics.

In October 2014, the protest movement Pegida (Patriotic Europeans against the islamization of the West) emerged in Dresden demonstrating, inter alia, against 'islamization', 'unchecked mass immigration', 'genderization', international trade treaties and further European integration of nation states (Pegida, 2015). Offshoots of the movement formed in cities across the country and Pegida immediately received a great share of media attention. But Pegida was not the only political newcomer in German politics: The AfD (Alternative for Germany) was founded in February 2013, has since shifted to the right and achieved striking electoral successes in elections for the European and state parliaments. First systematic analyses of political scientists classified the AfD as 'right-wing populist' (Arzheimer, 2015; Berbuir, Lewandowsky, \& Siri, 2015) although the party defines itself as a party in the center of the ideological spectrum, a self-described Volkspartei.

In light of this populist surge and an anxious public due to the refugee crisis (infratest dimap, 2016), the established political parties faced considerable pressures to adapt. The CSU, for instance, has urged chancellor Angela Merkel and the CDU to make their liberal refugee policies much more restrictive. If not in policies, parties could at least adjust their political communication by picking up topics emphasized by populists in order to demonstrate responsiveness. In the German case, Facebook is particularly well suited for such personalized messages to citizens since it is the social network with the highest societal diffusion (Frees \& Koch, 2015). Considering the interactive nature of Facebook, especially politicians who frequently encounter users with populist leanings on their pages might be inclined to adjust their messages. In order to investigate these dynamics, we pose the following research questions.

(1) To which extent do the audiences of Pegida and political parties on Facebook overlap?

(2) To which extent do Pegida and political parties discuss similar topics?

(3) Does political communication by German parties increasingly converge to topics emphasized by populists?

Theoretically, the paper discusses the related literatures on online collective action, populism and party competition in western democracies. Empirically, we analyze Facebook posts by party accounts and individual representatives of Pegida and German 
political parties over a period of almost two years, starting in December 2014. First, we concentrate on overlaps in audiences according to two Facebook conventions: likes and comments. We then train topic models on all posts to estimate party specific topic probabilities and survey crowdworkers to which extent they perceive the identified topics as populist communication. In the analysis, we find considerable similarities between Pegida and AfD in terms of audiences and topics in comparison to other German parties. Niche parties engage to varying degrees with the topics populists emphasize, however, the governing parties CDU and SPD, clearly deemphasize those. Overall, the findings indicate that the considerable attention devoted to populist actors and shifts in public opinion due to the refugee crisis have left only moderate marks in political communication within the mainstream party system.

\section{Pegida, AfD and populist tendencies in Germany}

In this section, we provide background information on the recent emergence of populist groups in Germany and shifts in public opinion. We first focus on Pegida which started as a local protest movement meeting for demonstrations each Monday in Dresden. It emerged from a non-public Facebook discussion group created on October 112014. The movement reached its height in participation in January 2015 when up to 25,000 people participated in one Monday demonstration and branches had been founded in most major German cities (Vorländer, Herold, \& Schäller, 2016). Since then, the size of the crowds at Pegida's demonstrations and public attention to the movement have varied considerably. Yet Pegida regularly enters public debates, recently in October 2016, when its activists protested against the assembled political and media elites of the country who came to Dresden to celebrate the German national holiday.

Facebook is the main platform for Pegida to present its political opinions and organize collective action (Vorländer et al., 2016). ${ }^{1}$ As Pegida mostly refuses to talk to traditional media, its Facebook pages are the most exhaustive and, besides the speeches at the Monday demonstrations, the only textual manifestation of its policy positions. In contrast, Pegida did not create a Twitter account until January 2016. Arzheimer (2015) reports a similar preference for Facebook in case of the AfD. He relates this to the higher degree of control that an owner of a Facebook page can exert while debates on Twitter are publicly open and not subject to moderation (Arzheimer, 2015, p. 548). In terms of demographics, Facebook is a medium used by a considerable share of the German population, on a daily basis by $22 \%$ of Internet users while Twitter use in Germany still remains a 'special interest' (Frees \& Koch, 2015). This makes Facebook a more attractive medium for populist online communication. Accordingly, Pegida became increasingly active on Facebook and still attracts significant numbers of supporters online (Vorländer et al., 2016, pp. 21-22; see Section 5).

The AfD was founded by economics professors, businessmen and former members of the conservative and liberal parties CDU and FDP in 2013. It had predominantly been a Eurosceptic party criticizing the fiscal and monetary policies of the German government and the EU institutions during the Euro crisis (Arzheimer, 2015). But the AfD increasingly incorporated ideas critical of migration and Islam into its platform. This transition was accompanied by disputes between a nationalist and a liberal party wing, which ultimately led to a mass exodus of the latter, including party founder Bernd Lucke who proceeded to found the party ALFA. The internal disagreement

\footnotetext{
${ }^{1}$ The domain http://www.pegida.de even redirects to Pegida's Facebook page.
} 
about the official party position towards Pegida was among the central reasons for the party split (Korsch, 2016; Vorländer et al., 2016, pp. 39-43). These internal and public disputes notwithstanding, the AfD had considerable successes in the elections for the European parliament in 2014 gaining $7.1 \%$ of the German votes and winning seats in most elections for parliaments in the federal states since 2013. These electoral successes further strengthened the conservative forces in the party.

These two groups are part of a more general surge in populist sentiment in the country, expressed through polarized discussions on social media, high poll numbers for the AfD (up to $15 \%$ in national polls) and the party's electoral successes. Ongoing media coverage of protest events and their comments on the refugee crisis kept populist actors and positions on the public agenda. Furthermore, the refugee crisis laid bare considerable anti-immigration preferences in public opinion (infratest dimap, 2016). A recent study of Pegida makes the argument that the movement merely mirrors (preexisting) preferences of many citizens disconnected from the political system and its elites (Hein, 2017). In focusing on Pegida's social media activity, we thus not only aim to capture the communication of the movement, but regard it as a proxy for the political opinions of considerable segments of the German population.

Taken together, these developments have incited intense discussions in all German parties on how to address the grievances of citizens sympathizing with populist positions and actors.

\section{Related research and expectations}

The article is related to three rich research fields: social media use by protest movements, populist political communication and the literature on party competition. We review findings relevant for the present research questions and discuss expectations for our case.

\section{Social media use by social movements and populists}

Numerous studies focus on 'connective action' (Bennett et al., 2014), i.e. the use of social media for the mobilization of (loose) social movements (e.g. Bennett et al., 2014; González-Bailón \& Wang, 2016). This field mostly concentrates on successful mobilization periods like the Arab Spring or the Occupy Wall Street and 15M movements. However, protest movements also have more latent and potentially long-lasting effects on political systems after news cycles have moved on. Since 'elections and social movements are the two major forms of political conflict in democratic systems' (McAdam \& Tarrow, 2010, p. 532), the latter have historically influenced policies and party systems (McAdam \& Tarrow, 2010). For instance, while the Occupy Wall Street movement has waned after a few months without leading to abrupt political changes, its message on economic inequality nonetheless still influences the debate on economic policies (Bennett, 2012) and its activists contributed to Bernie Sanders' insurgent campaign in the Democratic presidential primaries (CNN, 2016).

Since social movements often articulate grievances resonating with significant shares of the population, they can have an impact even if they are unable to maintain a prominent public profile. An increasing salience of their core issues and shifts in public opinion create electoral incentives for political parties to adjust their party programs accordingly (Downs, 1957). In the interactive communication environment of social 
media, political communication of social movements, parties and ordinary citizens is meshed together much more fluidly than in a mass media setting with traditional gatekeepers (Chadwick, 2013). The direct exposure of party actors to genuine political communication from the grassroots might accelerate contagion mechanisms identified by McAdam and Tarrow (2010) such as the penetration and lobbying of parties by social movements (proactive movement mobilization) and the emulation of interactive communication strategies by political parties themselves (transferable innovations).

There are indications that social media is especially beneficial to movements and parties on the political right, a tendency that has not yet been picked up by the connective action literature. Online social networks allow populists to bypass traditional media gatekeepers and use more radical rhetoric than previously possible in the age of mass media (Engesser et al., 2016). Right-wing populist communication appeals directly to the people and is particularly suited for personalized frames tailored to the interactive user experience: '[...] these late modern hybrids invite followers to define "true citizens" as "people like me" (e.g., a white, hard-working native-born citizen) and not those immigrants who come to live off my hard-earned tax money' (Bennett, 2012, p. 23).

The narrow focus on social media use by movements from the political left needs to be reconsidered and synchronized with established research on populism (Bale, GreenPedersen, Krouwel, Luther, \& Sitter, 2010; Mudde, 2004; Reinemann, Aalberg, Esser, Strömbäck, \& de Vreese, 2016). In order to do this, we rely on a minimalist conceptualization of populism. According to Reinemann et al. (2016), populism emphasizes (1) the political will of the people, (2) criticizes political or economic elites and (3) agitates against 'out groups' like religious or ethnic minorities. As a 'thin ideology' (Mudde, 2004) populism is compatible with diverse ideologies and is used as a communication mode by political actors from across the political spectrum (Mudde, 2004; Reinemann et al., 2016).

Within the German party system, the AfD still characterizes itself publicly as a party from the middle of the ideological spectrum. Nonetheless, media commentators described Pegida and like-minded citizens as the new target groups of the AfD after the Euro crisis lost its momentum as the main mobilizing issue (Die Welt, 2015). And the assessment of political scientists is also clear: "Up to now the party in its ambiguity with links to both the self-declared "centre of society" and the far right is a functional equivalent for right-wing populism in Germany' (Berbuir et al., 2015, p. 174). Korsch (2016) recounts the evolving relationship between Pegida and AfD as one mostly determined by the internal struggles between competing factions within the AfD. He shows that since 2015, the increasingly dominant conservative party wing around Alexander Gauland and Bjrn Hcke advocated for a rapprochement between both groups. This tendency has accelerated in 2016 when Pegida openly advertised AfD contents on its Facebook page. We thus (1) expect that the AfD attracts the highest share of Pegida supporters and (2) that the AfD emphasizes populist issues in order to attract the voters with preferences similar to Pegida activists.

\section{Party competition and populism}

The literature on party competition in western democracies (that is, however, negligent of social movements) can help us to elaborate on the question if established parties engage with or avoid topics populists typically emphasize. Of particular importance here is the debate on issue competition versus positional competition (Green-Pedersen, 
2007). According to models of issue competition, also called saliency theory (Budge \& Farlie, 1983), parties stress the topics that fall within their core competency while avoiding issues on which their competitors are seen as more competent (see also 'issue ownership' theory). On the other hand, the positional competition model states that parties compete against each other emphasizing similar issues while proposing different solutions (Dolezal, Ennser-Jedenastik, Müller, \& Winkler, 2014; Downs, 1957). The core question in the context of our research question is therefore, whether parties enter or avoid issue areas introduced by populist challengers (Meguid, 2005; Mudde, 2004).

Meguid (2005) proposes a model of electoral success positing that established parties should either ignore topics stressed by niche parties in order to reduce their public salience or occupy them with converging positions. According to this logic, for which the author finds support using data from the Comparative Manifesto Project (CMP), niche parties, here populists, only gain electoral support if mainstream parties address their issues but with diverging positions. Additional studies confirmed that especially parties from the moderate right tend to adopt topics and positions by emerging rightwing (populist) parties, e.g. on immigration (Abou-Chadi, 2016; Bale, 2003). Other empirical studies, however, revealed an even more complex picture dependent upon the specifics of each party system. Bale et al. (2010) found that while social democratic parties in four European countries reacted to right-wing challengers with programmatic adjustments, these were far from uniform and confined by country-specific factors. Rooduijn, de Lange, and van der Brug (2014) could not identify shifts in party positions in five Western European countries as a reaction to populist challenges. In terms of reactions by parties to shifts in public opinion, Adams, Clark, Ezrow, and Glasgow (2006) showed that in contrast to mainstream parties, niche parties rarely adjust their policy positions and are punished electorally when they do. Williams and Spoon (2015) revealed that larger parties tend to react when public opinion becomes more Euroskeptic and also that governing parties are less responsive to such changes in public opinion on this core issue of populists.

We can take away that party size, party ideology and whether a party forms part of the government or the opposition should determine its strategy towards populist challenges. Yet the special character of German refugee policies makes it hard to formulate concrete expectations for each party regarding the adoption of populist topics. According to the literature, the CDU is predestined to incorporate populist topics and positions since it is a large moderate right party. However, its participation in the federal government and implementation of liberal refugee policies, which is idiosyncratic in terms of party ideology, severely restrict its room to maneuver. Similar cross-pressures apply to other parties as well, since all parties except the AfD and the CSU shared a principal consensus on the most salient topic during our research period, the refugee crisis.

\section{Research approach}

Our paper thus primarily takes an exploratory approach that nonetheless adds to previous research in several regards: first, in addition to programmatic adjustments within the party system, we also analyze the populist movement Pegida. Second, prior research mostly concentrated on party manifestos which should be regarded as artifacts of strategic considerations tailored primarily towards media audiences. Party programs therefore do not necessarily reveal populist shifts in everyday political communication. Our approach using data from social media is able to cover a non-party actor in Pegida 
and a party that had not produced a coherent party program until 2016, the AfD. Third, the categorization of contents is unsupervised, i.e. our approach covers the universe of empirically relevant topics and is therefore more flexible than the fixed topic categories found in manifesto datasets such as the CMP. This, for instance, allows us to assess various important facets of the refugee crisis that would have been concealed within one or two higher-level CMP categories.

The limitations of such a design are that we rely on topic saliences that are better suited for the analysis at a larger scale than issue positions which are more complex to operationalize. ${ }^{2}$ Moreover, relevant co-correlates in the context of political and media systems influence the strategic considerations of political actors. Especially in light of the concurrence of AfD's and Pegida's rise with the refugee crisis, we cannot clearly attribute shifts in topic saliences by parties to one of those three factors. Nevertheless, our research design holds exogenous influences constant since actors from all analyzed political groups are similarly exposed to ongoing events and news cycles. Given their extended presence on the social network, Facebook is an ideal data source to compare political communication by Pegida, AfD and established political parties.

\section{Methods}

Data collection. For our empirical analysis, we retrieved all posts from the public Facebook pages of Pegida and German political parties, as well as posts by their politicians. The selection of Pegida accounts relied on a list of affiliated local branches presented on the main Pegida Facebook page. ${ }^{3}$ In addition to the main party Facebook accounts, we collected the posts from politicians affiliated with the political parties AfD, CDU, CSU, FDP, Grne (Bündnis 90/Die Grünen), Linke (Linkspartei) and SPD at the federal level. ${ }^{4}$ Moreover, we mined the respective public user comments and likes on the posts of the main Facebook accounts of each group. Our research period starts on the day of the opening of the Pegida Dresden account on December 29, 2014 and lasts until August 17, 2016. For the data mining, we connected to the Facebook Graph API using the R package Rfacebook (Barberá, 2016). The final dataset is described in Table 1.

It is noteworthy that our data does not contain posts and comments that had either been deleted by users, moderators of the political Facebook pages or by Facebook, since our data mining was conducted ex post on August 17, 2016. Therefore, the dataset depicts the curated self-presentation and as such the strategic considerations of political actors our research aims to reveal. Furthermore, we only chose the parties with a realistic chance of passing the electoral threshold of $5 \%$ required for representation in the Bundestag. Fringe parties like the Pirates or the NPD predominantly discuss niche topics and do not necessarily tailor their messages strategically in order to appeal to

\footnotetext{
${ }^{2}$ In further research, we will extend our approach to positional competition.

${ }^{3}$ There are indications that the newly created Pegida branches are more radical than the Dresden chapter (Vorländer et al., 2016, p. 69). However, since the accounts are listed and liked by the main Pegida site, they are clearly regarded as part of the movement by its leaders.

${ }^{4}$ We relied on several data sources. We thank Martin Fuchs and his website Pluragraph for providing us with lists of the social media accounts of sitting parliamentarians in the federal parliament (Bundestag) and leading politicians of the non parliamentarian parties AfD and FDP. The list of AfD politicians also contains the candidates for the German federal election 2013 (Kaczmirek \& Mayr, 2015) except the ones who have left the AfD and joined ALFA, the new party of AfD founder Lucke. To increase the share of messages coming from official party accounts, which we assume communicate more strategically than individual politicians, we included the accounts of the parties in the federal states.
} 
large shares of voters at the federal level.

User behavior analysis. In the first step of our analysis, we concentrate on behavioral patterns of users engaging with posts created by political actors on Facebook. ${ }^{5}$ More specifically, we are interested in the exposure of the seven main party accounts to Pegida supporters. To measure this exposure, we extracted all users that liked or commented on posts at least once. ${ }^{6}$ We then calculated the overlaps between unique users of each party (or Pegida) in the likes and comments layers (see Equation 1).

$$
\text { overlap }_{\text {group } x, y}=\frac{\mid \text { group } x \cap \text { group } y \mid}{\mid \text { group } x \mid}
$$

Text analysis. In the second step of our study, we concentrate on the contents of political communication. Using the posts by Pegida, parties and politicians in the dataset described above, we analyze the extent to which the political groups discuss different topics and how these topic mixtures change over time. In order to identify the topics contained in our dataset, we employ Latent Dirichlet Allocation (LDA). LDA is an unsupervised Bayesian form of latent semantic analysis introduced by Blei, Ng, and Jordan (2003). Our decision to use LDA, a mixed membership model, is based on the assumption that Facebook posts can contain more than one topic per post. For the analysis of different groups' topic mixtures, we average the topic distributions of each post by each group. For analyzing how a group's topic mixture changes over time, we average the topic distributions of the group's posts for each day.

To reduce the linguistic complexity of the posts we applied the following preprocessing steps: First, we removed German stopwords, links, words shorter than three characters, as well as very frequent words and words occurring in less than 10 posts. Next, we removed the names of sitting members of the German parliament. Finally, we removed all posts that had less than five words remaining. All of these steps serve the goal of obtaining interpretable topics depicting the political issues discussed in the data (Grimmer \& Stewart, 2013). After preprocessing, the dataset consists of 244,237 posts, with a vocabulary of 50,166 unique terms.

We then trained LDA with different levels of granularity (50 and 100 topics) on the preprocessed corpus. For training, we used the Collapsed Variational Bayes inference schema (Teh, Newman, \& Welling, 2006), as implemented by Ramage and Rosen (2010) with 200 iterations. The model priors $\alpha$ and $\beta$ were set to 0.1 and 0.01 , respectively. These low prior values reflect our beliefs that Facebook posts tend to cover few topics in one post (as opposed to many different topics) and that the covered topics contain relatively few, specific words. The two separate model runs resulted in similar topic groupings, yet with different levels of granularity. The most important criterion when evaluating topic model outputs should be their substantive fit in the context of a specific research question (Grimmer \& Stewart, 2013, p. 286). In that regard, the configuration with 100 topics produced the most appropriate topics which we will evaluate and use in the empirical analysis.

\footnotetext{
${ }^{5}$ The Facebook Graph API does not provide information on who likes Facebook pages themselves.

${ }^{6}$ Pegida's account was deleted by Facebook on 22 July because of 'instances of hate speech'. Therefore we could only conduct the behavioral analysis based on data retrieved in a previous data crawl. Figure 1 is consequently based on all unique users engaging with a post by one of the eight main accounts before February $20,2016$.
} 
Table 1. Description of the Facebook dataset.

\begin{tabular}{lcccc}
\hline Party & Accounts & Posts & Likes & Comments \\
\hline AfD & 128 & 68,875 & $14,363,982$ & $1,865,905$ \\
CDU & 180 & 63,057 & $3,772,036$ & $1,011,581$ \\
CSU & 34 & 13,227 & $4,571,095$ & 648,375 \\
FDP & 103 & 38,275 & $7,296,749$ & 800,281 \\
Grne & 53 & 23,065 & $2,432,002$ & 426,665 \\
Linke & 55 & 27,406 & $7,387,873$ & 588,105 \\
Pegida & 25 & 34,282 & $5,318,992$ & 850,672 \\
SPD & 172 & 87,115 & $4,739,772$ & 613,699 \\
\hline Total & 750 & 355,302 & $49,882,501$ & $6,805,283$ \\
\hline
\end{tabular}

\section{Results and discussion}

\section{User behavior analysis}

To answer our first research question on overlaps between audiences of Pegida and political parties, we calculated the intersections of unique users in the likes and comments layers (see Equation 1). The underlying assumption is that a high exposure to Pegida supporters creates incentives to address topics popular with these users. Figure 1 displays the fraction of the unique user base of party $x$ (left column) also having liked or commented at least one post by party $y$ (bottom row). Therefore, the values for party pairs (and Pegida-party pairs) differ in the boxes above and beneath the grey diagonal.

Several findings in Figure 1, Panel A stand out. First, 33\% of Pegida likers, 79,333 users, liked contents on the AfD site at least once. This is the highest overlap of all party pairs. In return, of AfD unique likers, $21 \%$ liked Pegida contents, making this party pair the one with the highest reciprocal affinity. Second, of CSU unique users, considerably shares also liked AfD contents (21\%) and Pegida contents (11\%). In contrast, only $6 \%$ of CSU sympathizers also liked a post by the sister party CDU, whereas it is $22 \%$ the other way round. Furthermore, the CSU is the only established party with a certain appeal to Pegida likers (13\%) and AfD likers (15\%). Third, the overlaps between other party pairs are mostly negligible. Only FDP users allocate likes widely to other parties. Besides that, we observe an ideological sorting along party lines in the likes of mainstream political parties. The clearest conglomeration of user bases takes place between Pegida, AfD and CSU. The common denominator between these three groups is their position furthest right on the political spectrum and their opposition to liberal refugee policies.

In Panel B of Figure 1, we see a much more heterogeneous picture. Pegida and AfD still have the highest reciprocity in terms of users commenting on both sites. Yet their users and those of all other parties distribute comments much more evenly than likes.

The differences between the likes and comments layers indicate that these conventions are used for different purposes and therefore have diverging social meanings when regarded as aggregate counts. Likes can be regarded as a sign of political support which Pegida users mostly attribute to posts of AfD, but also to the CSU which criticized the governments' refugee policy (in which the CSU is participating, ironically). Comments, in contrast, are oftentimes also used to voice criticism and therefore allocated rather evenly across the political spectrum. The diverging use of likes and comments is 


\section{(A) Likes}

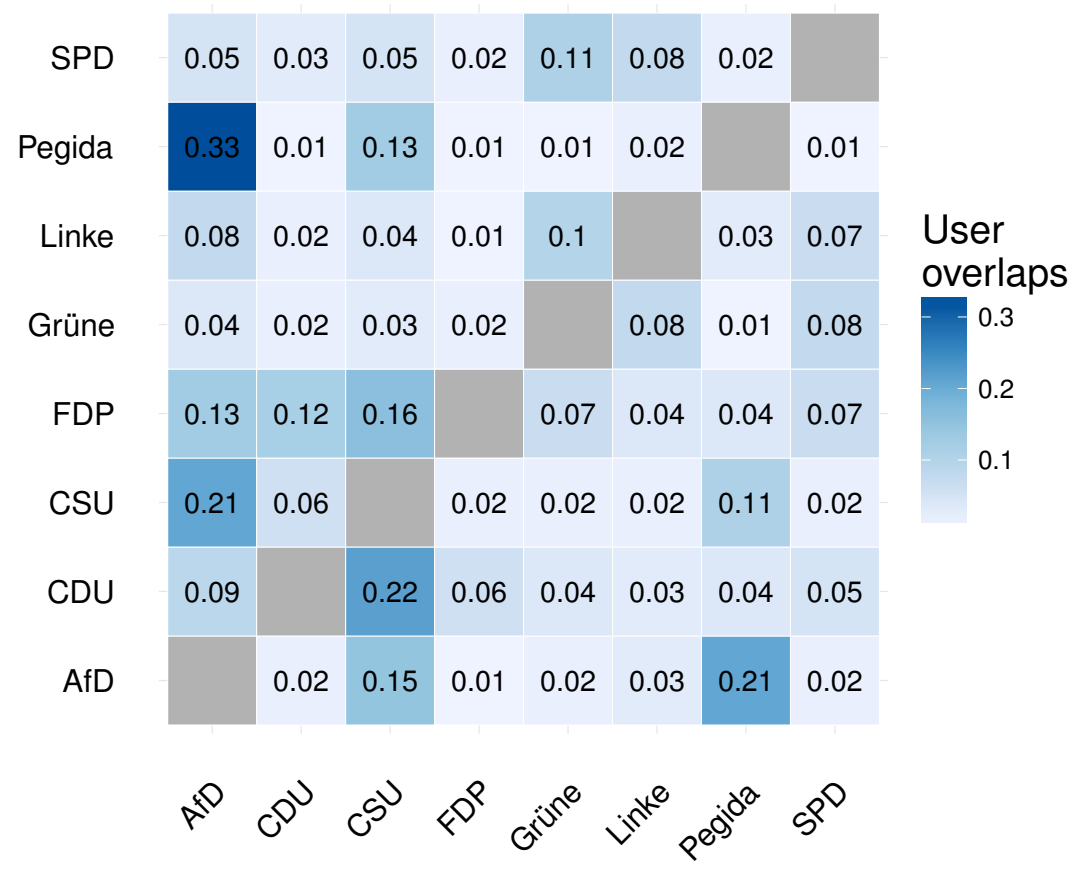

(B) Comments

\begin{tabular}{|c|c|c|c|c|c|c|c|c|c|}
\hline SPD & 0.14 & 0.17 & 0.12 & 0.07 & 0.12 & 0.08 & 0.08 & & \\
\hline Pegida & 0.2 & 0.06 & 0.08 & 0.02 & 0.05 & 0.03 & & 0.05 & \\
\hline Linke & 0.14 & 0.12 & 0.11 & 0.06 & 0.12 & & 0.08 & 0.14 & $\begin{array}{l}\text { User } \\
\text { overlans }\end{array}$ \\
\hline Grüne & 0.19 & 0.16 & 0.14 & 0.08 & & 0.09 & 0.11 & 0.16 & 0.20 \\
\hline FDP & 0.17 & 0.22 & 0.15 & & 0.15 & 0.09 & 0.07 & 0.18 & 0.10 \\
\hline CSU & 0.2 & 0.13 & & 0.05 & 0.09 & 0.05 & 0.12 & 0.1 & 0.05 \\
\hline CDU & 0.21 & & 0.19 & 0.1 & 0.14 & 0.08 & 0.11 & 0.19 & \\
\hline AfD & & 0.09 & 0.12 & 0.03 & 0.07 & 0.04 & 0.18 & 0.07 & \\
\hline
\end{tabular}

Figure 1. Overlaps in unique users per group. 
in line with findings from Twitter, where retweets are a stronger predictor of partisan homophily than @-mentions (Lietz, Wagner, Bleier, \& Strohmaier, 2014).

The results show that the supporter bases of Pegida and AfD are the most similar ones across the German political spectrum. This could influence political communication by the AfD and, reciprocally, populist communication by the AfD should attract Pegida supporters. Other German parties besides the CSU are exposed much less frequently to users also active on the Pegida site.

\section{Topics addressed by Pegida and political parties}

By implication, the previous analysis suggests that political communication by Pegida and AfD should be rather similar as well, since it resonates with an identical group of politically interested people of considerable size. We take to the content level of political actors' posts to investigate this systematically. For this, we train the LDA topic model on the full corpus of posts by Pegida, parties and individual politicians. As described in Section 4, we use the model with 100 topics.

To narrow down the scale to politically interpretable and thus substantively relevant topics, three of the authors independently coded the model outputs as relevant topics on policies or contemporary events, or of no substantive interest (with an inter-rater reliability of Fleiss' Kappa $=0.706, p<0.000$ ). This means that 'stopword topics' containing Facebook specific language such as 'like, follow, share' or parliamentary procedural topics containing 'vote, debate, speaker' were dropped, but also topics on constituency service which, while being interpretable, cover procedural instead of substantive issues and are therefore of no relevance here. We also excluded party specific topics with predominantly organizational information and unique language only used by a particular group. This procedure left us with 46 topics of substantive interest out of the original 100. The authors independently assigned titles based on the top scoring words for each topic in Appendix A1 and decided on the few ambiguous cases consensually. The model identifies a mix of generally relevant policy fields but also topics more specific to our research period like the Euro or refugee crises.

For our subsequent content analysis, we calculated the average topic probabilities for each party in the 46 topics (Figure 2). The higher its share in a topic, the more heavily a party referred to it in their Facebook posts. It is important to note that the y-axes are flexible which means that each plot has an individual value range. From the perspective of the literature on party competition, the results are ambiguous. On the one hand, there is a skew towards one or few parties in most of the topics which is exactly what issue saliency theory predicts (Budge \& Farlie, 1983). A lot of the variation can be explained by the diverging core competencies parties have, e.g. Grne overemphasize Energy/climate policy while SPD and Linke frequently talk about Social policy - Unions. On the other hand, various topics like Terror attacks in Europe are well balanced with similar topic shares by several groups across the political spectrum. This reveals the limitations of an approach relying exclusively on topic salience. In some topics, the positional competition model which distinguishes between different political preferences on identical topics (Dolezal et al., 2014) is more applicable.

To shed light on similarities between groups, we statistically compare the vectors of party specific topic probabilities across the 46 topics. For this, we calculate the cosine similarities of these distributions for all party pairs. ${ }^{7}$ Figure 3 shows that with a cosine

\footnotetext{
${ }^{7}$ The results are robust when using the Jensen-Shannon divergence as a distance metric.
} 


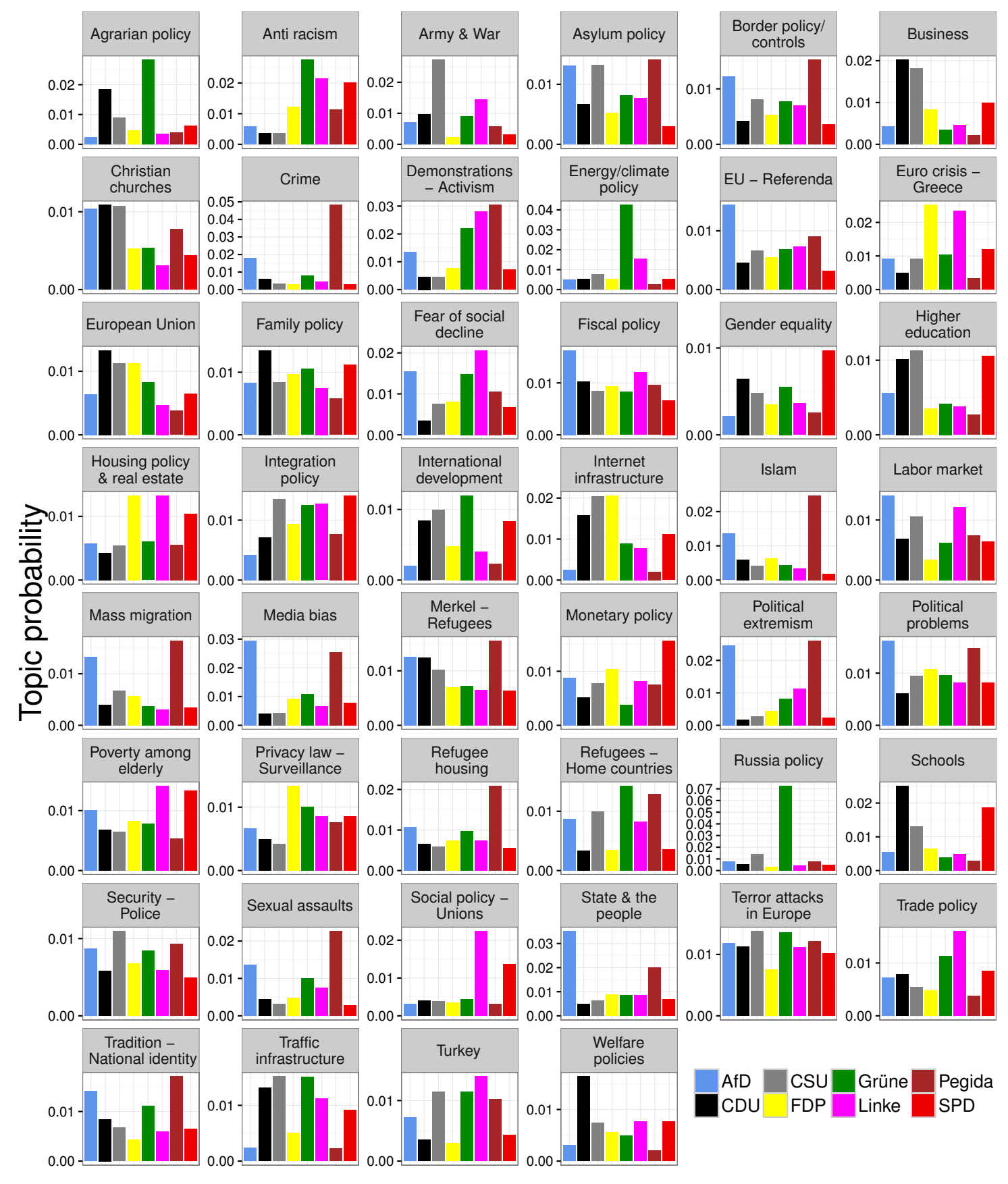

Figure 2. Topics addressed by Pegida and political parties. 


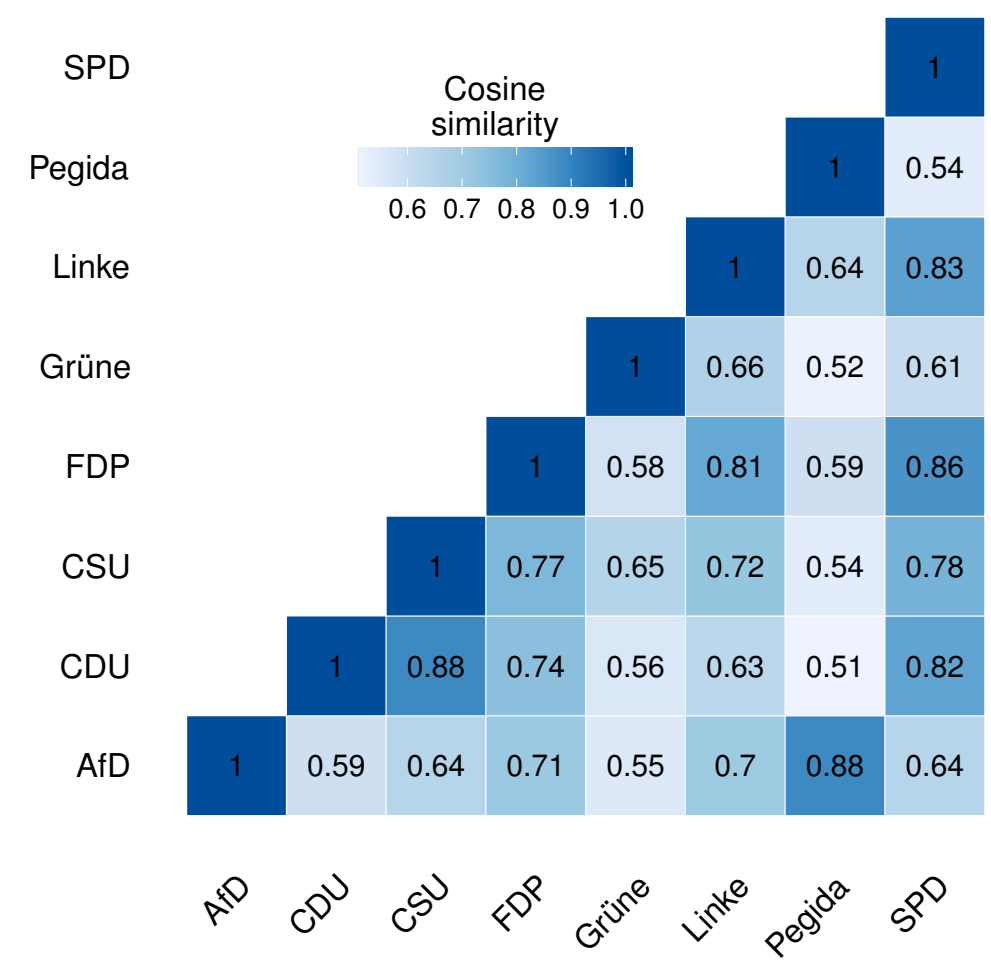

Figure 3. Cosine similarities between topic distributions of Pegida and political parties.

similarity of 0.88 , Pegida and AfD have the most similar distributions (together with the sister parties CDU and CSU). ${ }^{8}$ As it is to be expected, the coalition partners at the federal level CDU and SPD also discuss similar issues. Counterintuitively, the FDP vector has a high congruence with the topic vectors of Linke and SPD, which are both parties from the left. It seems that on Facebook, the multifaceted FDP emphasizes its progressive side, e.g. in the topic Privacy law - Surveillance, but also has high probabilities jointly with leftist parties in topics like Euro crisis - Greece or Housing policy $\mathcal{E}$ real estate on which the FDP certainly proposes diverging positions.

\section{Topics emphasized by populists}

The high cosine similarity between Pegida and AfD shows that they not only attract similar users but also discuss similar political issues. To assess the extent to which the identified topics should be considered as typical items on a populist agenda, external judgments are needed. For this, we set up a survey on the crowdsourcing platform CrowdFlower. ${ }^{9}$ While it is not feasible to train non-experts sufficiently to code a concept like populism that is even disputed in the academic literature (Reinemann et al., 2016), crowdworkers provide a more diverse set of opinions than a small group of authors and research assistants. Moreover, crowd tasks scale up well, i.e. many respondents can be recruited to judge 46 topics in a swift and affordable way. This survey is probably not representative of the German population. However, German crowdwork-

\footnotetext{
${ }^{8}$ As a robustness test, we compared the cosine similarities between all groups in the two models with 50 and 100 topics resulting in a Spearman rank correlation of $\rho=0.84$. The party specific topic distributions are therefore very similar independent of the number of topics.

${ }^{9}$ https://www.crowdflower.com
} 
ers are exposed to media coverage on and political communication by populist actors. In essence, their ratings represent the extent to which they perceive different topics as salient on a populist agenda.

German crowdworkers were first provided the three criteria of populist communication defined by Reinemann et al. (2016) (see Section 3). Then they were asked about their opinion on the extent to which the ten most typical words per topic (Appendix A1) represent populist communication. For this, they had to rate the keywords in each topic on a scale from 1 (not at all populist) to 7 (clearly populist). Three attention checks were included in the survey to detect and filter out spammers. Of the 150 crowdworkers we surveyed, 107 passed all the attention checks. Only the ratings by the latter respondents were kept in our analysis.

The average populism rating per topic is listed in Table 2 . The aggregated allocation of topics to ratings is almost normally distributed $(\mathrm{N}=46$, mean $=3.86$, median $=3.78)$. While the standard deviations indicate considerable disagreement between respondents, the topic means were similar in a repetition of the survey (30 respondents; Spearman correlations between both surveys: $\rho=0.92)$. In order to evaluate these ratings, we qualitatively assess the topics in the top ranks according to the three pillars of populist communication defined by Reinemann et al. (2016). To give the reader insights how the topics manifest themselves in messages, we listed the five Facebook posts with the highest probability in the top 10 topics in the Online Appendix.

In terms of criticism of elites, the topic Media bias stands out, as demonstrated by negative attributions like 'truth', 'propaganda' or 'lügenpresse' (Media liars), one of the most salient slogans of Pegida (see Appendix A1). A substantial amount of criticism towards elites is also contained in the topics EU - Referenda and Merkel Refugees. However, Figure 2 shows that even though Pegida and AfD share the highest probabilities, other parties also contribute to the latter topics, which implies that their interpretation by populists is contested by differing partisan positions.

Multiple topics focus on issues related to perceived out-groups. Most evidently, aspects of refugee policy like Asylum policy, Border policy/controls, Islam, Mass migration and Refugee housing are central aspects in populist communication. The vocabulary on Political extremism indicates that it serves the purpose to define 'out groups' by circumscribing an own core of supporters from groups at the other end of the political spectrum perceived as being violent (e.g. 'Antifa', a left wing anti-racist group). Moreover, crowdworkers attached a high populist rating to the wordlists in the topic Sexual assaults, which clearly refers to the incidents on New Years' Eve 2015/2016 ('Cologne') when women were perpetrated predominantly by men from the Middle East and Northern Africa. In all of these topics, Pegida and AfD again share the highest probabilities (Figure 2).

Three topics are particularly emphasized by leftist parties. Fear of social decline and Poverty among elderly address latent fears of a social decline and are not only emphasized by Grne, Linke and SPD but also the right-wing AfD. Meanwhile, Trade policy concerns issues typically made salient by the political left such as international treaties like TTIP or CETA or the drilling technique fracking. One defining feature of our minimalist conceptualization of populism as a 'thin ideology' (Mudde, 2004) is its openness to diverse ideologies. Accordingly, leftist actors like Bernie Sanders, Syriza in Greece, the Five Star movement in Italy and Podemos in Spain have all been labeled as populists by media observers and academics (Mudde, 2015).

Two of the ratings in the top 15 are rather ambiguous. The deal concerning refugees with Turkey is frequently discussed by populists, but at the same time other parties emphasize different aspects of Turkey policies. The topic Anti racism is primarily de- 
Table 2. Crowdworker ratings per topic.

\begin{tabular}{lcc}
\hline Topic & Populism rating & Standard deviation \\
\hline Media bias & 5.53 & \\
Border policy/controls & 5.29 & 1.58 \\
Political extremism & 5.27 & 1.49 \\
Islam & 5.19 & 1.51 \\
Turkey & 5.00 & 1.55 \\
Asylum policy & 4.93 & 1.69 \\
Sexual assaults & 4.84 & 1.80 \\
Mass migration & 4.77 & 1.78 \\
Refugee housing & 4.70 & 1.61 \\
Merkel - Refugees & 4.70 & 1.77 \\
EU - Referenda & 4.64 & 1.84 \\
Anti racism & 4.59 & 1.72 \\
Fear of social decline & 4.56 & 1.95 \\
Poverty among elderly & 4.53 & 1.63 \\
Trade policy & 4.46 & 1.76 \\
Russia policy & 4.42 & 1.70 \\
Demonstrations - Activism & 4.28 & 1.57 \\
Integration policy & 4.23 & 1.83 \\
Terror attacks in Europe & 4.12 & 1.94 \\
Army \& War & 3.99 & 2.01 \\
Euro crisis - Greece & 3.93 & 1.86 \\
Privacy law - Surveillance & 3.92 & 1.70 \\
Refugees - Home countries & 3.80 & 1.65 \\
Fiscal policy & 3.78 & 1.86 \\
Crime & 3.77 & 1.74 \\
Security - Police & 3.70 & 1.75 \\
State \& the people & 3.66 & 1.62 \\
Housing policy \& real estate & 3.63 & 1.64 \\
Monetary policy & 3.61 & 1.74 \\
Labor market & 3.57 & 1.68 \\
International development & 3.54 & 1.87 \\
Social policy - Unions & 3.26 & 1.68 \\
Christian churches & 3.20 & 1.74 \\
Tradition - National identity & 3.16 & 1.81 \\
Traffic infrastructure & 3.04 & 1.79 \\
Agrarian policy & 3.01 & 1.76 \\
Welfare policies & 2.97 & 1.79 \\
Political problems & 2.93 & 1.82 \\
European Union & 2.92 & 1.71 \\
Energy/climate policy & 2.79 & 1.76 \\
Internet infrastructure & 2.79 & 1.64 \\
Family policy & 2.65 & 1.68 \\
Gender equality & 2.64 & 1.73 \\
Business & 2.55 & 1.61 \\
Higher education & 2.47 & 1.59 \\
Schools & 2.30 & 1.62 \\
\hline & & 1.67 \\
\hline
\end{tabular}


voted to mobilize against right-wing tendencies and was perceived by crowdworkers as a form of populism at the other end of the political spectrum. Both results point toward the limitations of the necessarily parsimonious information provided to crowdworkers and the need to further distinguish topical foci and positions of parties within identical topics.

Within the top ranks, there are also no clear references to the arguably most important pillar of populism, the promise to advocate for the pure interests of the people. But as noted by Reinemann et al. (2016), the communicative construction of the people can also be made implicitly by contrasting this idealized homogeneous body to the problems attached to elites and out-groups. German populists predominantly prefer frames attacking perceived outsiders rather than making references to the Volk, a restraint which might be related to the extensive use of this notion in the propaganda of the Third Reich. Yet recent public statements of AfD party leaders like the initiative of Frauke Petry to exculpate the term vlkisch of its troublesome past indicates that these communicative taboos are not off-limits to populists anymore.

\section{Temporal patterns in topic salience}

In our final analysis, we analyze which topics parties emphasize over time, in particular topics with a populist appeal. For this, we use the crowdsourced populism ratings to calculate a topic salience weighted by populism rating (TSPR) for each political group $x$ per day $t$ via the equation

$$
T S P R_{x t}=\sum_{k=1}^{K} \text { salience }_{k x t} * \text { rating }_{k},
$$

where $K=46$ is the number of topics. In order to identify shifts over time, we use these daily values as input to fit LOESS regressions per group. The regressions predict the daily values by taking into account the neighboring data points in the time series. This data fitting technique smooths the considerable daily volatility in the raw time series data, removes seasonality effects and facilitates the identification of trends.

Several patterns can be observed in Figure 4. First, Pegida and AfD have the highest values of topic salience weighted by populism rating. Their time series reached peaks during the height of the refugee crisis in the second half of 2015. Afterwards, they seem to have shifted their focus to other topics, however, with an upward trend again since April 2016.

Second, the two biggest parties CDU and SPD which form a coalition in the federal government have the lowest values on this scale. As the refugee crisis unfolded, they addressed related issues, yet deemphasized them again in 2016 .

Third, the time series for the smaller 'niche' parties CSU, FDP, Linke and Grne are quite volatile. When inspecting the individual time series of parties in each topic, it becomes clear that FDP and Linke emphasized topics with a higher populism weight mostly as a reaction to external events like the increasing influx of refugees in 2015 or the events from New Years' Eve 2015/2016 in Cologne. Topic salience does not reveal their positions on these issues, yet several of their leading politicians, for instance Sarah Wagenknecht (Linke) and Christian Lindner (FDP), publicly criticized the refugee policies by Angela Merkel's government and both have been accused of flirting with populist stances.

Furthermore, the aggregated time series mask heterogeneous topical foci of parties. 


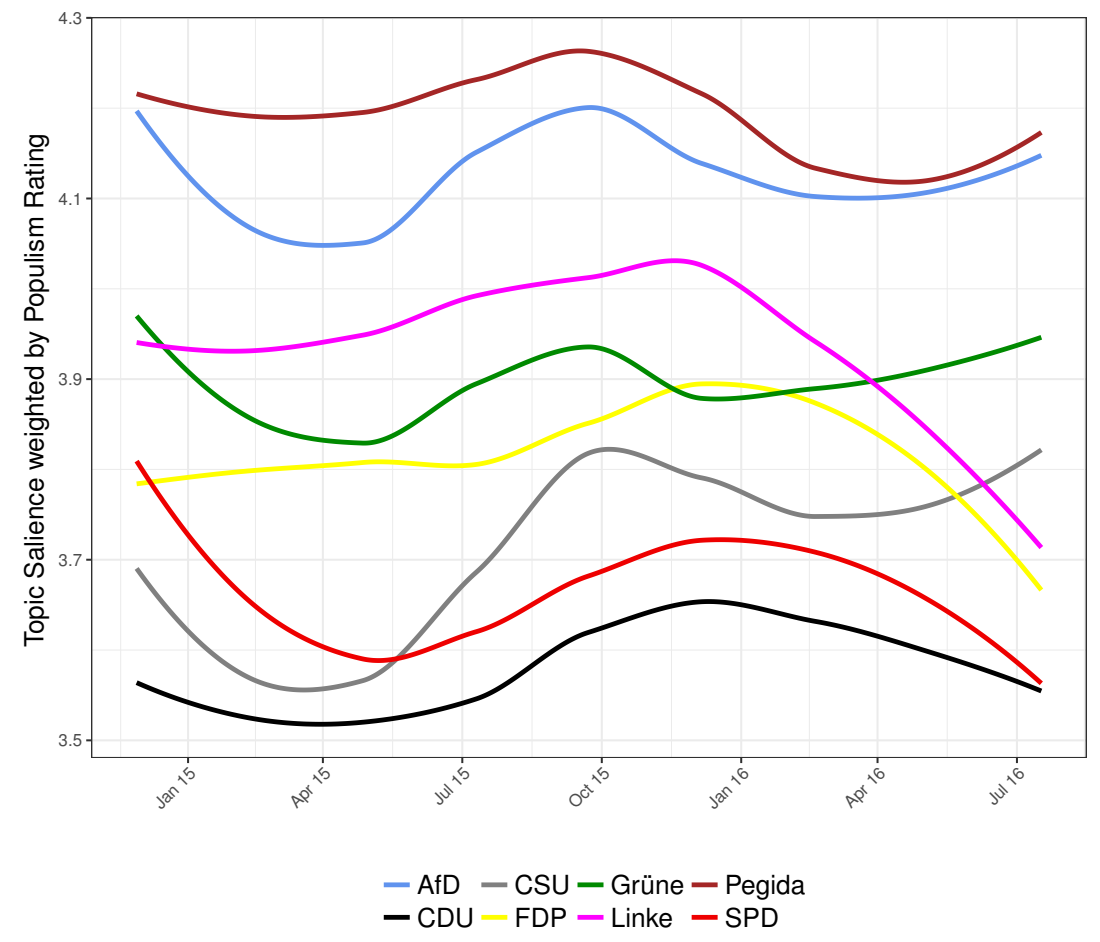

Figure 4. Topic salience weighted by populism rating over time.

The Grne and Linke are also prominent here because they emphasize their core issues like Trade policy or Fear of social decline. Yet the Grne also put a special focus on Asylum policy, which implies that the party actively contests the interpretation of the topic by populists, e.g. in the debate on deportations of asylum seekers. The CSU on the other hand, increasingly talked about refugee policies by putting a particular focus on Asylum policy, Border policy/controls, and Mass migration.

The two bigger governing parties clearly deemphasized topics that are typically stressed by populists, in particular on refugee and migration policies. The marginalization of these issues by CDU and SPD, on which their performance was rated very critically by the public (infratest dimap, 2016), support core assumptions of the original saliency theory in party competition (Budge \& Farlie, 1983). However, the findings need to be complemented by more complex analyses of party positions. Especially the results for niche parties are less consistent but rather point to positional differences (Meguid, 2005), for instance, 'accommodative strategies' by the CSU and 'adversarial strategies' by the Grne. The strategies how to address populist challenges can principally be located between these two poles, but certainly vary between parties as well as over time within parties.

Although generally at a high level, there is also significant temporal volatility in populism weighted topic salience by Pegida and AfD. Especially the drop off in the beginning of 2016 is of interest. Did Pegida and AfD concentrate on more moderate issues after the influx of refugees narrowed down? In order to answer this we will look at several of the topics in which Pegida and AfD share high probabilities (Figure 2).

Figure 5 shows that AfD as well as Pegida have adjusted to shifts in public attention and identified new salient topics to which they can attach their populist message. The AfD increasingly discusses $E U$ - Referenda focusing on the Brexit and referenda in other European countries. Pegida has clearly stressed the topics Crime and Sexual 


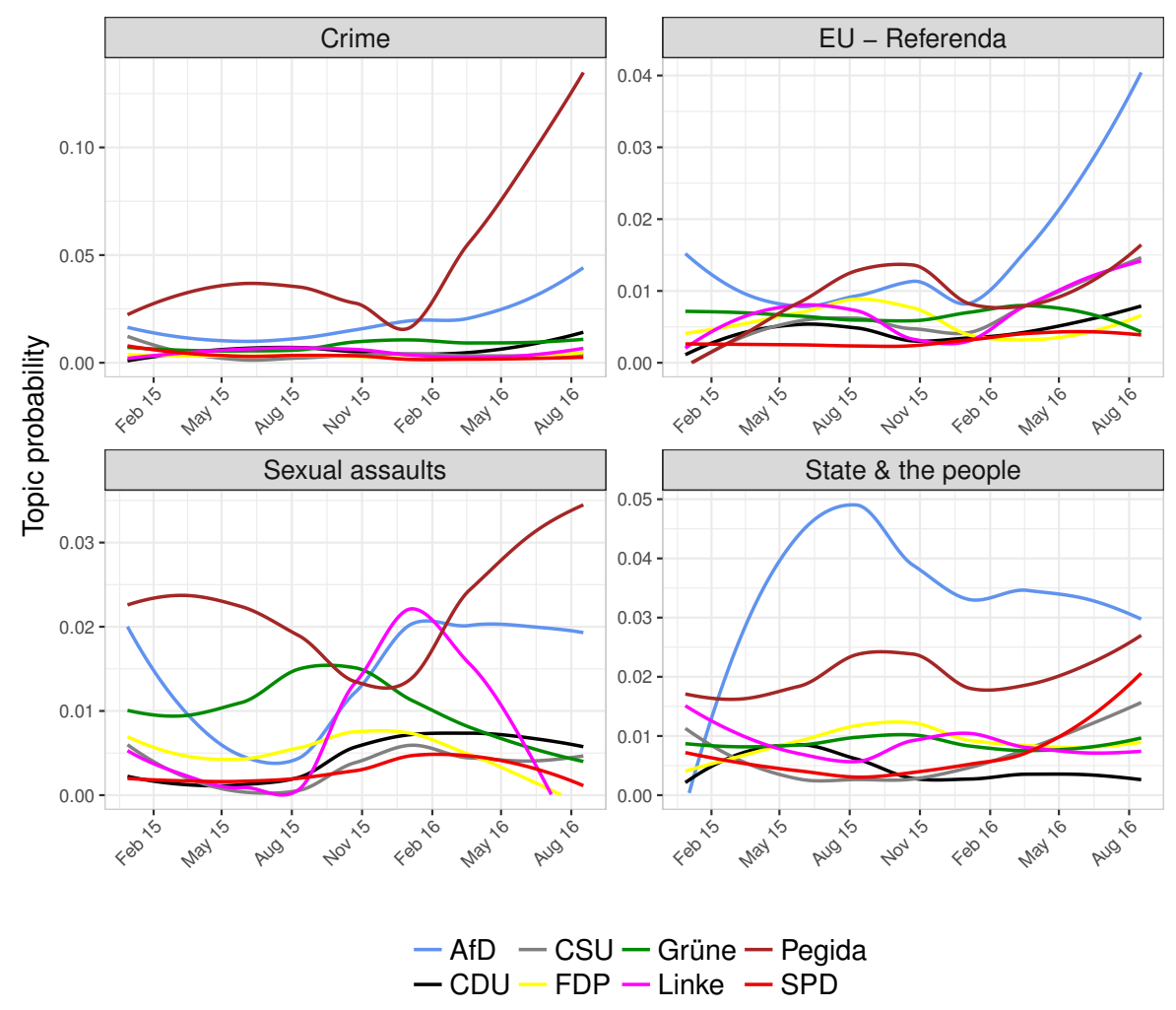

Figure 5. Topics characteristic for Pegida and AfD.

assaults since the New Years' Eve 2015/2016.

It is also worth to look at the two topics in which Pegida and AfD share high probabilities not rated as particularly populist by crowdworkers because their use by populists only becomes apparent through their context in messages (see Online Appendix). First, when looking at posts regarding Crime, it becomes clear that AfD and Pegida relate criminal activity to the presence of refugees in the country. The use of this frame targeting the sense of security of audiences can be compared to 'personalized frames' of leftist movements (Bennett et al., 2014) and fits well with the populist aspiration to protect the people from dangers instigated by out-groups. Second, Pegida and AfD attach particular relevance to the State $\& 6$ the people. This topic is the clearest manifestation that both also discuss general questions regarding the state of the polity.

\section{Conclusion}

This paper set out to analyze online communication by populist actors and mainstream political parties in Germany. The results show that Pegida and AfD appeal to similar target groups by emphasizing rather unique topics in their communication on social media. While party leaders repeatedly distanced the AfD from more radical right-wing groups and Pegida in particular, our findings challenge the self-presentation of the AfD as a party of the political center. These results add to the literature on populism in western democracies that has so far exclusively focused on populist challengers in the form of political parties. The analysis of Pegida's Facebook activity also 
demonstrated that not only leftist social movements are adept in using social media and personalized frames (Bennett, 2012), but also counterparts at the opposite end of the ideological spectrum. In a counterfactual situation without the emergence of Pegida, which revealed the substantial resonance of right-wing positions in German society, the more nationalist forces in the AfD might not have prevailed in the internal party struggle during 2015. Since then, the AfD has firmly established itself as the melting pot of populism in the German party system.

Coupled together, populist actors in Germany have a considerable audience that is constantly mobilized against the Altparteien and perceived out-groups. We analyzed whether established parties have adapted to these pressures by addressing similar topics in their political communication. Our analysis over time revealed limited evidence for an increasing emphasis of core populist topics in messages by established parties. The parties on the political left, Grne and Linke emphasized some of their core issues like trade policy which can be subsumed under a minimalist definition of populism. The CSU increasingly addressed topics emphasized by populists but still at a significantly lower level than Pegida and AfD. However, whether these fluctuations are causally related to right-wing populism is beyond the scope of this study. These shifts, which we interpret tentatively, are in line with previous inconclusive results regarding a programmatic contagion in the mainstream party system induced by right-wing challengers (Bale et al., 2010; Rooduijn et al., 2014).

From the perspective of the literature on party competition, the most interesting finding is that the conservative party CDU deemphasized populist topics which runs contrary to previous studies (Abou-Chadi, 2016; Bale, 2003). German politics during our research period should be regarded as a special case since a 'grand coalition' consensually implemented liberal refugee policies. CDU, SPD and all established parties with the exception being the CSU - deemphasized related issues, which nonetheless remained salient due to external events. This created a vacuum that populists exploited. In other countries, such a consensus across parties is not to be expected and especially conservative parties position themselves more to the right than Angela Merkel's CDU. In order to test to which extent these results hold in other contexts, our methodology could be applied to further cases, since data can be gathered ex post via the Facebook Graph API. In general, the approach can be used for the analysis of substantive issues other than populism and in various disciplines, whenever a constellation is present in which new groups or ideas enter an established social system.

We also want to address the limitations of this study. Several uncertainties accompanied the data collection process, since we could not retrieve posts that had been deleted by holders of political accounts, users or Facebook moderators. Furthermore, a systematic coding at the level of posts may be more accurate than at the topic level, but is on the other hand more complex to implement in terms of the anonymization required to conceal the sender, costs, time and personnel, even when deploying crowdworkers. Moreover, the topics identified by the unsupervised LDA model are naturally dependent on the underlying data from a specific research period. A promising direction for future work could be to apply a polylingual labeled topic model (Posch, Bleier, Schaer, \& Strohmaier, 2015) which is able to incorporate both predefined labels related to populist rhetoric and additional information about the posts such as the language characteristics of user comments. Considering the variety of methodological opportunities, quantitative text analysis holds great promise to improve the analysis of populist communication beyond the infrequently published party manifestos. 


\section{Notes}

\footnotetext{
${ }^{1}$ The domain http://www.pegida.de even redirects to Pegida's Facebook page.

${ }^{2}$ In further research, we will extend our approach to positional competition.

${ }^{3}$ There are indications that the newly created Pegida branches are more radical than the Dresden chapter (Vorländer et al., 2016, p. 69). However, since the accounts are listed and liked by the main Pegida site, they are clearly regarded as part of the movement by its leaders.

${ }^{4}$ We relied on several data sources. We thank Martin Fuchs and his website Pluragraph for providing us with lists of the social media accounts of sitting parliamentarians in the federal parliament (Bundestag) and leading politicians of the non parliamentarian parties AfD and FDP. The list of AfD politicians also contains the candidates for the German federal election 2013 (Kaczmirek \& Mayr, 2015) except the ones who have left the AfD and joined ALFA, the new party of AfD founder Lucke. To increase the share of messages coming from official party accounts, which we assume communicate more strategically than individual politicians, we included the accounts of the parties in the federal states.

${ }^{5}$ The Facebook Graph API does not provide information on who likes Facebook pages themselves.

${ }^{6}$ Pegida's account was deleted by Facebook on 22 July because of 'instances of hate speech'. Therefore we could only conduct the behavioral analysis based on data retrieved in a previous data crawl. Figure 1 is consequently based on all unique users engaging with a post by one of the eight main accounts before February 20, 2016 .

${ }^{7}$ The results are robust when using the Jensen-Shannon divergence as a distance metric.

${ }^{8}$ As a robustness test, we compared the cosine similarities between all groups in the two models with 50 and 100 topics resulting in a Spearman rank correlation of $\rho=0.84$. The party specific topic distributions are therefore very similar independent of the number of topics.

${ }^{9} \mathrm{https}$ ://www.crowdflower.com
}

\section{Disclosure statement}

No potential conflict of interest was reported by the authors.

\section{Notes on contributors}

Sebastian Stier is a postdoctoral researcher in the Department Computational Social Science at GESIS - Leibniz Institute for the Social Sciences in Cologne. He studies the role of the Internet in political communication relying on theoretical approaches and methods from Comparative Politics, Communication Sciences and Computational Social Science.

Lisa Posch is a doctoral student in the Department Computational Social Science at GESIS. Her research is focused on human intelligence tasks and topic models, and their application within the Computational Social Science domain.

Arnim Bleier is a postdoctoral researcher in the Department Computational Social Science at GESIS. His research interests are in the field of Computational Social Science. In collaboration with social scientists, he develops Bayesian models for the content, structure and dynamics of social phenomena.

Markus Strohmaier is a Full Professor of Web-Science at the Faculty of Computer Science at the University of Koblenz-Landau and scientific director of the Department Computational Social Science at GESIS. His main research interests include Web-Science, Computational Social Science and Data Science.

\section{References}

Abou-Chadi, T. (2016). Niche party success and mainstream party policy shifts - 
How green and radical right parties differ in their impact. British Journal of Political Science, 46(02), 417-436.

Adams, J., Clark, M., Ezrow, L., \& Glasgow, G. (2006). Are niche parties fundamentally different from mainstream parties? The causes and the electoral consequences of Western European parties' policy shifts, 1976-1998. American Journal of Political Science, 50(3), 513-529.

Arzheimer, K. (2015). The AfD: Finally a successful right-wing populist eurosceptic party for Germany? West European Politics, 38(3), 535-556. doi:

Bale, T. (2003). Cinderella and her ugly sisters: The mainstream and extreme right in Europe's bipolarising party systems. West European Politics, 26 (3), 67-90.

Bale, T., Green-Pedersen, C., Krouwel, A., Luther, K. R., \& Sitter, N. (2010). If you can't beat them, join them? Explaining social democratic responses to the challenge from the populist radical right in Western Europe. Political Studies, 58(3), 410-426. doi:

Barberá, P. (2016). Package 'Rfacebook'. CRAN.

Bennett, W. L. (2012). The personalization of politics: Political identity, social media, and changing patterns of participation. The ANNALS of the American Academy of Political and Social Science, 644(1), 20-39. doi:

Bennett, W. L., Segerberg, A., \& Walker, S. (2014). Organization in the crowd: Peer production in large-scale networked protests. Information, Communication \& Society, 17(2), 232-260. doi:

Berbuir, N., Lewandowsky, M., \& Siri, J. (2015). The AfD and its sympathisers: Finally a right-wing populist movement in Germany? German Politics, 24(2), 154-178. doi:

Blei, D. M., Ng, A. Y., \& Jordan, M. I. (2003). Latent dirichlet allocation. Journal of Machine Learning Research, 3, 993-1022.

Budge, I., \& Farlie, D. (1983). Explaining and predicting elections: Issue effects and party strategies in twenty-three democracies. London: George Allen \& Unwin.

Chadwick, A. (2013). The hybrid media system: Politics and power. Oxford: Oxford University Press.

CNN. (2016). Occupy Wall Street rises up for Sanders. Retrieved 19 October 2016, from http://edition.cnn.com/2016/04/13/politics/occupy-wall -street-bernie-sanders-new-york-primary

Die Welt. (2015). Vorauseilende Pegida-Schelte hilft nur der AfD. Retrieved 10 October 2016, from http://www.welt.de/debatte/kommentare/ article136261979/Vorauseilende-Pegida-Schelte-hilft-nur-der-AfD .html

Dolezal, M., Ennser-Jedenastik, L., Müller, W. C., \& Winkler, A. K. (2014). How parties compete for votes: A test of saliency theory. European Journal of Political Research, 53(1), 57-76. doi:

Downs, A. (1957). An economic theory of democracy. New York, NY: Harper \& Row.

Engesser, S., Ernst, N., Esser, F., \& Büchel, F. (2016). Populism and social media: How politicians spread a fragmented ideology. Information, Communication $\mathcal{E}$ Society. doi:

Frees, B., \& Koch, W. (2015). Internetnutzung: Frequenz und Vielfalt nehmen in allen Altersgruppen zu. Media Perspektiven, 9, 366-377.

González-Bailón, S., \& Wang, N. (2016). Networked discontent: The anatomy of protest campaigns in social media. Social Networks, 44(1), 95-104. doi:

Green-Pedersen, C. (2007). The growing importance of issue competition: The changing nature of party competition in Western Europe. Political studies, 55(3), 
607-628.

Grimmer, J., \& Stewart, B. M. (2013). Text as data: The promise and pitfalls of automatic content analysis methods for political texts. Political Analysis, 21(3), 267-297. doi:

Hein, T. (2017). Pegida als leerer Signifikant, Spiegel und Projektionsfläche - eine Einleitung. In T. Hein (Ed.), Pegida als Spiegel und Projektionsfläche (pp. 1-31). Wiesbaden: Springer VS.

infratest dimap. (2016). ARD-DeutschlandTREND Februar 2016. Retrieved 10 November 2016, from http://www.infratest-dimap.de/fileadmin/user _upload/dt1602_bericht.pdf

Kaczmirek, L., \& Mayr, P. (2015). German Bundestag Elections 2013: Twitter usage by electoral candidates. GESIS Data Archive. doi:

Korsch, F. (2016). Natürliche Verbündete? Die Pegida-Debatte in der AfD zwischen Anziehung und Ablehnung. In A. Häusler (Ed.), Die Alternative für Deutschland: Programmatik, Entwicklung und politische Verortung (pp. 111-134). Wiesbaden: Springer Fachmedien Wiesbaden. doi:

Lietz, H., Wagner, C., Bleier, A., \& Strohmaier, M. (2014). When politicians talk: Assessing online conversational practices of political parties on Twitter. In Proceedings of the 8th International AAAI Conference on Weblogs and Social Media (pp. 285-294). Palo Alto, CA: AAAI Press.

McAdam, D., \& Tarrow, S. (2010). Ballots and barricades: On the reciprocal relationship between elections and social movements. Perspectives on Politics, 8(2), 529-542. doi:

Meguid, B. M. (2005). Competition between unequals: The role of mainstream party strategy in niche party success. American Political Science Review, 99 (03), $347-359$.

Mudde, C. (2004). The populist Zeitgeist. Government and Opposition, 39(4), 542563. doi:

Mudde, C. (2015). The problem with populism. Retrieved 7 November 2016, from https://www.theguardian.com/commentisfree/2015/feb/17/problem -populism-syriza-podemos-dark-side-europe

Pegida. (2015). Zehn Thesen in Dresden angeschlagen - Dafür geht PEGIDA auf die Strae. Retrieved 10 June 2016, from https:// pegidaoffiziell. wordpress.com/2015/02/16/zehn-thesen-in-dresden -angeschlagen-dafur-geht-pegida-auf-die-strase

Posch, L., Bleier, A., Schaer, P., \& Strohmaier, M. (2015). The polylingual labeled topic model. In Joint German/Austrian Conference on Artificial Intelligence (Künstliche Intelligenz) (pp. 295-301).

Ramage, D., \& Rosen, E. (2010). Stanford topic modeling toolbox. Retrieved 28 July 2016, from http://nlp.stanford.edu/software/tmt/tmt-0.4/

Reinemann, C., Aalberg, T., Esser, F., Strömbäck, J., \& de Vreese, C. H. (2016). Populist political communication. Toward a model of its causes, forms, and effects. In T. Aalberg, F. Esser, C. Reinemann, J. Stromback, \& C. De Vreese (Eds.), Populist Political Communication in Europe (pp. 12-25). New York, NY: Routledge.

Rooduijn, M., de Lange, S. L., \& van der Brug, W. (2014). A populist Zeitgeist? Programmatic contagion by populist parties in Western Europe. Party Politics, 20(4), 563-575. doi:

Teh, Y. W., Newman, D., \& Welling, M. (2006). A collapsed variational Bayesian inference algorithm for Latent Dirichlet Allocation. In Proceedings of the 20th 
Annual Conference on Neural Information Processing (pp. 1353-1360). Cambridge, MA: MIT Press.

Vorländer, H., Herold, M., \& Schäller, S. (2016). PEGIDA: Entwicklung, Zusammensetzung und Deutung einer Empörungsbewegung. Wiesbaden: Springer VS.

Williams, C., \& Spoon, J.-J. (2015). Differentiated party response: The effect of Euroskeptic public opinion on party positions. European Union Politics, 16(2), 176-193.

\section{Appendix A. Top words in each topic.}

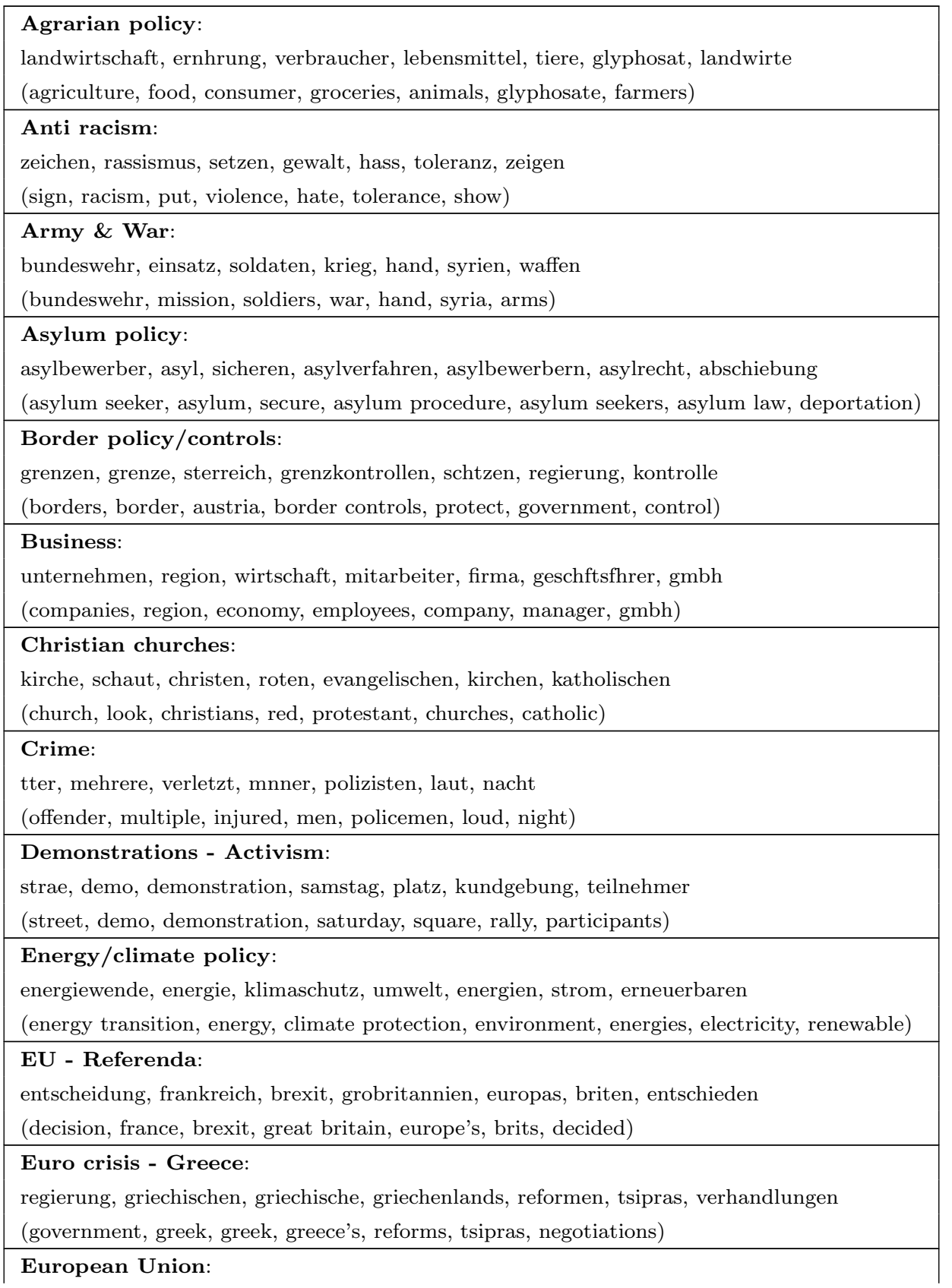


europischen, union, europische, brssel, kommission, gemeinsame, parlament

(european, union, european, brussels, commission, common, parliament)

Family policy:

familie, eltern, kindern, familien, bildung, schulen, kind

(family, parents, children, families, education, schools, child)

\section{Fear of social decline:}

folgen, angst, bevlkerung, druck, zeigen, setzt, fhrt

(consequences, fear, population, pressure, show, put, lead)

\section{Fiscal policy:}

geld, milliarden, millionen, kosten, steuerzahler, zahlen, haushalt

(money, billions, millions, costs, taxpayer, numbers, budget)

\section{Gender equality:}

foto, phototheknet, mnner, amt, schwesig, brandenburger, manuela

(photo, phototheknet, men, office, schwesig, brandenburg, manuela)

\section{Higher education:}

bildung, prof, forschung, ausbildung, universitt, wissenschaft, oldenburg

(education, prof, research, qualification, university, science, oldenburg)

\section{Housing policy \& real estate:}

fordert, wohnungen, wohnen, wohnraum, fordern, forderung, sozialen

(demand, apartments, live, housing space, demand, claim, social)

\section{Integration policy:}

integration, flchtlingen, helfen, ort, aufnahme, schutz, flucht

(integration, refugees, help, location, accommodation, shelter, escape)

\section{International development:}

zusammenarbeit, entwicklung, menschenrechte, botschafter, nationen, internationalen

(cooperation, development, human rights, ambassador, nations, international)

\section{Internet infrastructure:}

wirtschaft, chancen, digitalisierung, raum, bildung, digitale, lndlichen

(economy, chances, digitalization, space, education, digital, rural)

\section{Islam:}

islam, muslime, religion, islamischen, muslimischen, islamisierung, staat

(islam, muslims, religion, islamic, muslim, islamization, state)

\section{Labor market:}

mindestlohn, zahl, zahlen, prozent, arbeitsmarkt, millionen, deutlich

(minimum wage, number, numbers, percentage, labor market, millions, distinct)

\section{Mass migration:}

zuwanderung, einwanderung, migranten, bevlkerung, regeln, integration, gesetze

(immigration, immigration, migrants, population, rules, integration, laws)

\section{Media bias:}

medien, politiker, presse, lgenpresse, wahrheit, berichterstattung, journalisten

(media, politicians, press, lying press, truth, coverage, journalists)

\section{Merkel - Refugees}

kanzlerin, bundeskanzlerin, flchtlingspolitik, spricht, flchtlingskrise, merkels, worte

(chancellor, chancellor, refugee policy, talks, refugee crisis, merkel's, words)

\section{Monetary policy:}

ezb, banken, urteil, bargeld, bank, abschaffung, bundesverfassungsgericht

(ecb, banks, verdict, cash, bank, abolishment, constitutional court)

\section{Political extremism:}

gewalt, linken, antifa, rechts, kampf, angriffe, politisch 
(violence, leftists, antifa, rightists, fight, attacks, political)

\section{Political problems:}

probleme, verantwortung, problem, lsung, situation, lage, handeln

(problems, responsibility, problem, solution, situation, condition, act)

\section{Poverty among elderly:}

rente, armut, soziale, hartz, einkommen, steuern, erhhung

(pension, poverty, social, hartz, income, taxes, increase)

\section{Privacy law - Surveillance:}

bild, maas, vorratsdatenspeicherung, links, minister, rechts, teilt

(bild, maas, data preservation, left, minister, right, shares)

\section{Refugee housing}

asylbewerber, derzeit, unterbringung, flchtlingen, pro, unterkunft, untergebracht

(asylum seeker, currently, accomodation, refugees, pro, shelter, accommodated)

\section{Refugees - Home countries:}

syrien, osten, mittelmeer, millionen, nahen, afrika, irak

(syria, east, mediterranean, millions, middle, africa, iraq)

\section{Russia policy}

russland, ukraine, usa, polen, nato, syrien, russischen

(russia, ukraine, usa, poland, nato, syria, russian)

\section{Schools:}

schler, schlerinnen, schule, klasse, bad, schlern, schulen

(pupils, pupils, school, class, bath, pupils, schools)

\section{Security - Police:}

sicherheit, polizisten, innere, schutz, stellen, personal, ffentlichen

(security, policemen, internal, protection, positions, staff, public)

\section{Sexual assaults:}

kln, straftaten, klner, tter, gewalt, bergriffe, sexuelle

(cologne, crime, cologne's, perpetrator, violence, assaults, sexual)

\section{Social policy - Unions:}

beschftigten, gewerkschaften, leiharbeit, dgb, arbeitgeber, arbeitsbedingungen, sozial

(employees, unions, contract work, dgb, employers, labor conditions, social)

\section{State \& the people:}

art, staat, nmlich, volk, vllig, weise, eher

(manner, state, namely, people, entirely, way, rather)

\section{Terror attacks in Europe:}

paris, terror, opfer, gedanken, angehrigen, anschlag, opfern

(paris, terror, victims, thoughts, relatives, attack, casualties)

\section{Trade policy:}

ttip, ceta, freihandelsabkommen, fracking, usa, abkommen, verhandlungen

(ttip, ceta, free-trade treaty, fracking, usa, treaty, negotiations)

\section{Tradition - National identity}

kultur, buch, geschichte, heimat, gehrt, stck, sprache

(culture, book, history, home, belongs, part, language)

Traffic infrastructure:

mdb, bndnis, 90die, ausbau, bahn, region, verkehr (mdb, bndnis, 90die, expansion, railroad, region, traffic)

\section{Turkey:}

trkei, erdogan, trkischen, trkische, kurden, regierung, isis

(turkey, erdogan, turkish, turkish, kurds, government, isis) 


\section{Welfare policies:}

pflege, versorgung, gesundheit, patienten, behinderung, behinderungen, inklusion

(care, provision, health, patients, disability, disabilities, inclusion) 